\title{
異高同時選択取水によるダム貯水池の 水質保全効果に関する研究 \\ STUDY ON THE SELECTIVE WITHDRAWAL SYSTEM WITH SIMULTANEOUS OPERATION OF MULTI GATES IN A RESERVOIR
}

\author{
矢島 啓 ${ }^{1} \cdot$ 吉川 栄 ${ }^{2}$ \\ Hiroshi YAJIMA and Sakae KIKKAWA
}

1正会員 博(工) 鳥取大学助教授 工学部土木工学科（广 680-8552 鳥取市湖山町南4-101）

2正会員 西谷技術コンサルタント株式会社 都市・環境部（テ682-0025 倉吉市八屋354-1）

\begin{abstract}
Nowadays, a selective withdrawal system (SWS) in a dam is essential for the conservation of water quality in the reservoir. However, we cannot say that the operation of SWS has been fully examined in Japan. On the other hand, in the United States, there are many methods of operation. For example, some dams use three or more gate levels, operated simultaneously, to blend the desired water quality. To make clear the efficiency of this operation, we conducted numerical simulations using the one-dimensional water quality simulation model, DYRESM-CAEDYM, developed by CWR. The simulated results indicated that this operation has a greater potential for controlling water quality in the reservoir, especially when it is combined with the surface and mid-layer intake operation.
\end{abstract}

Key Words : Selective withdrawal system, multi gates, reservoir, water quality, DYRESM-CAEDYM.

\section{1. はじめに}

ダム貯水池における水質問題として, 濁水長期化現象, 冷水放流問題, 富栄養化などが挙げられる. これらの水 質対策として今日一般的にダムに備えられている選択取 水設備（以下，SWSと略）は，1900年代初めに，貯水池 低層部の水質悪化問題に対応するため, ダム底部の放水 バルブからのフラッシュという形で始まり，現在の形に 発展していった ${ }^{1)}$. 当初SWSは, 理論よりも実務が先行 していが，1960年代になり，選択取水時の取水層の厚さ や取水量に関する理論的研究が始まった ${ }^{1)}$. その後, 数 值計算モデルの開発・発展に伴い，鈆直 1 次元モデルを 用いてダム貯水池の様々な水深から選択取水を行ったと きの水質への影響を評価する研究 ${ }^{2}$ や，水理解析シミュ レーションモデルとLPやDPなどの最適化手法との組み 合わせによりSWSの運用計画を検討する研究 3 (3) も行わ れた. さらに, 数值計算モデルが水温だけでなく, 濁度 やDOなどの水質も計算対象とするようになると，2次元 の水理水質計算モデルを用い，SWSがダム湖の水温躍層 の低下効果や濁水長期化現象の制御機効果を持つことも 明らかにされている5).このような研究面での発展を受 け，高知県にある早明浦ダム（昭和50年3月完成）では， 建設時に設置した表面取水設備を，その後SWSへと改造 を行い; 既往の操作に関する課題を踏まえ，2次元の水 理水質計算モデルにより, 洪水の規模と濁度の状況に応 じたSWSの運用方式を構築している ${ }^{6)}$.
日本におけるSWSは，1970年代後半の施工以来，多く のダムで設置されている7). この運用状況を(財)ダム水 源地環境整備センターが全国21のダムを対象に行った調 查では, 常時表層取水が16ダム, 底部取水が 1 ダム, 出 水や期別による弾力的運用が4ダムであった ${ }^{8)}$. このよ うに表層取水が多いのは, 冷水放流を防ぐためであるが, その運用面においては，十分検討されているとはいえな い. 今後は, 早明浦ダムのような詳細な検討が必要と なってくると考えられる. このような日本の状況に対し， 米国では, 1970年には全米のダムを対象にしたSWSのア ンケート調査を行い，その規模等についての一覧表を作 成している ${ }^{9}$. その後, データの更新と新たな調查項目 を含めて全米40のダムを対象にアンケート調查を実施し ている ${ }^{10)}$.これによると, SWSの設置理由としては, 水 温対策が32ダム，DO対策が17ダム，濁度対策が5ダムと なっている. 日本ではダム貯水池内のDOがSWSで議論 されることが少ないのとは異なっている. また，この調 査で明らかにされていることは, 調査対象中の8ダムに おいて，2つ以上のゲートを同時に操作し，それらの水 を混合させ希望の水質にしたものを放流する運用を行っ ている事例がみられた. このような状況を鑑みると，日 本におけるSWSの運用は, ダムの歴史が長い米国と比較 してまだ検討の余地があると言える.

そこで本研究では, 現在, 日本で運用事例がほとんど ない同時に2つ以上の取水ゲートを運用した取水を行い それらを混合して放流する異高同時SWSを検討するため, 
西オーストラリア大学Centre for Water Research (CWR) で開発された 1 次元貯水池流動解析モデルDYRESM (DYnamic REservoir Simulation Model) と水質予測モデ ルCAEDYM (Computational Aquatic Ecosystem Dynamics Model）をカップリングしたDYRESM-CAEDYM ${ }^{11)}$ を利 用し, 異高同時選択取水を含むSWS運用の違いが，ダム 貯水池内の長期的な水温成層構造と水質に与える影響及 び放流水に与える影響を明らかにする．ただし，道奥ら が指摘しているように, オリジナルのDYRESMコード では考慮されていない，洪水時の流入密度流による鉛直 混合過程を組み込み，日本のように先鋭なハイドログラ フを持つ流入河川の影響を考慮できる改良型モデルを使 用した ${ }^{22}$. また, 計算においては, 鈆直方向に分割する 最小層厚を $1 \mathrm{~m}$, 最大層厚を $2 \mathrm{~m}$ と, 計算時間間隔を 1 時 間とした.

\section{2. 本研究で使用するモデルの検証}

\section{（1）検証ダムと計算対象年}

モデルの検証のため, 江の川流域の広島県高田郡八千 代町に位置し, 堤高 $50 \mathrm{~m}$ ·堤頂長 $300 \mathrm{~m}$ ·総貯水容量 4700 万 $\mathrm{m}^{3}$ の規模を有する重カコンクリート式の国土交通省直 轄の多目的ダムである土師ダムのデータを使用する. 土 師ダムの平均的な年間回転率は約 9.8 であり, 検証計算 は直近 10 年のうち, 各年で変動する気象条件や流況に対 する再現性を検討するため,「洪水年」と「渴水年」を 計算対象年として選定した. 選定された対象年は, 渴水 年として1994年, 洪水年として 1997 年 $\left(300 \mathrm{~m}^{3} / \mathrm{s}\right.$ 程度の中 規模洪水が4回)，1999年 $\left(1,000 \mathrm{~m}^{3} / \mathrm{s}\right.$ 程度の大規模洪水があ る)の出水形態の異なる3 年である. 平均貯水容量に対す る洪水時の日流入量は, 1997年の中規模洪水で $60 \%$ 以上, 1999年の大規模洪水で $160 \%$ 程度となっている.

\section{（2）検証計算結果}

検証計算は，土師ダム管理所が貯水池の湖心で行って いる定期観測の 1 月における観測值を年初めの計算初期 値として行った. パラメータの同定は, 水温 $\rightarrow \mathrm{DO} \rightarrow$ 栄 養塩類 $\rightarrow$ 植物プランクトン（動物プランクトンは考慮し ていない）の順番を基本に，各パラメータ間のフィード バックを考慮しながら行った. 検証計算で得られた水 温・DO・Chl.aの表層と最下層の結果を図-1に示す. 図 中, ダム湖心で得られた表層（水深 $0.1 \mathrm{~m}$ ) と最下層（湖 底上 $1 \mathrm{~m})$ における観測結果も示している.

図-1(a), (d), (g)に示される水温の検証結果は, 洪水年, 渴水年にかかわらず再現精度の高いことが分かる.また, 図-1(b), (e), (h)に示すDOの検証結果は, 4月以降, 表層 と最下層の水温差が大きくなり成層が発達するのに伴い, 下層が貧酸素化していく様子が再現できている. 次に, 図-1(c), (f), (i)に示すChl.aの検証結果をみると, Chl.a濃度 は, 植物プランクトンに含まれる合計量であり, 水温や

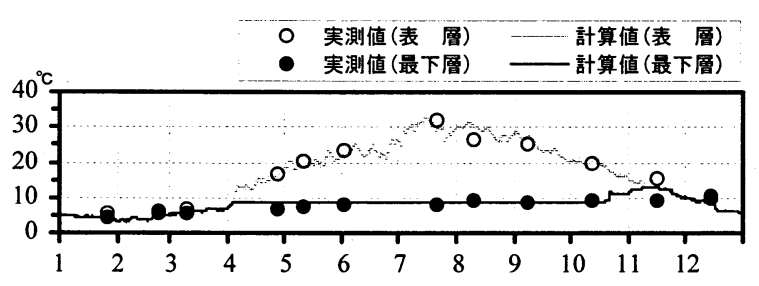

(a) 1994年 水温

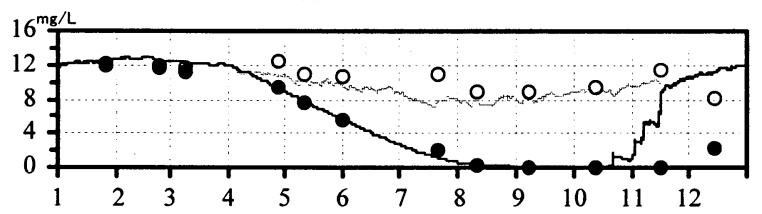

(b) 1994年 DO

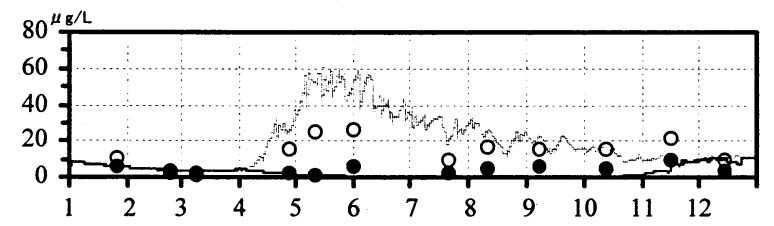

(c) 1994年 Chl.a

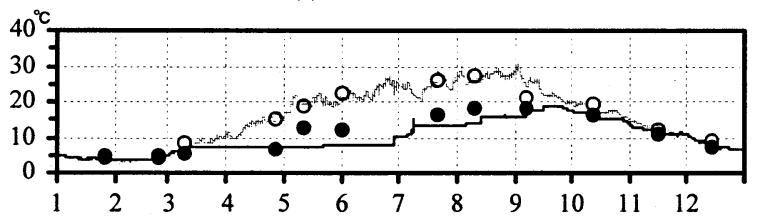

(d) 1997年 水温

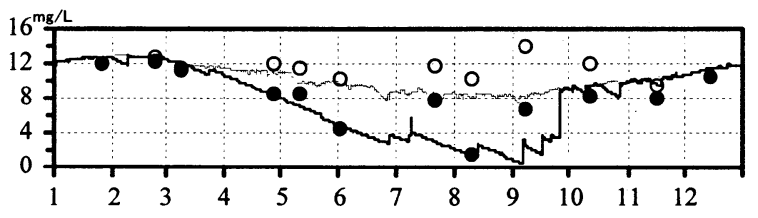

(e) 1997年 DO

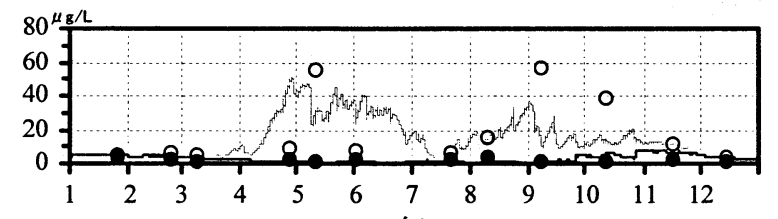

(f) 1997年 Chl.a

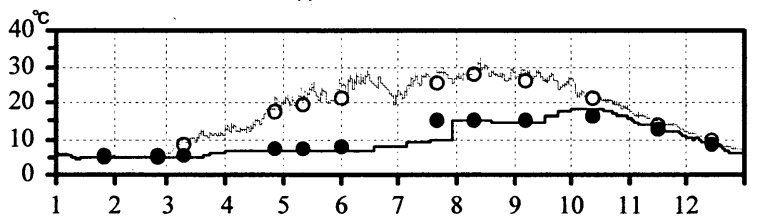

(g) 1999年 水温

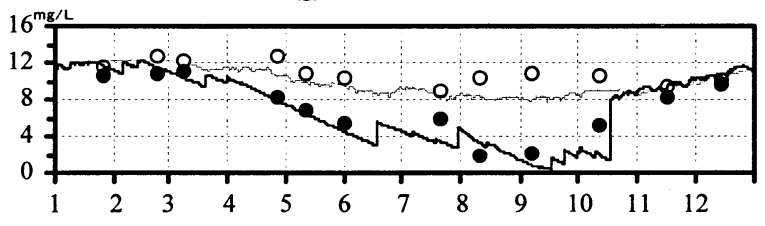

(h) 1999年 DO

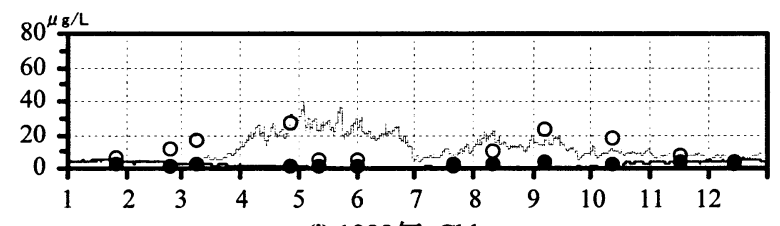

(i) 1999年 Chl.a

図-1 各年の水温・DO $\cdot \mathrm{Chl} . \mathrm{a}$ の検証結果 
DOに比べて観測で得られた值の代表性に問題もあるが， その基本的な変化傾向や濃度レベルは十分再現できてい ることは明らかである. 特に, 検証計算における植物プ ランクトンとして, 珪藻類・緑藻類・藍藻類の 3 種類を 考虑しているが, 各年とも, 春先4月頃からは珪藻類が, 少し送れて緑藻類が, 最後に藍藻類が成長する傾向があ り，この特徵は，1997年に現地で土師ダム管理所が行っ たプランクトン調査による結果とも一致していた.

このように, 本研究で用いるモデルは1次元モデルで あるが，長期的なダム湖の水質予測には，十分な精度で 用いることができることが明らかとなった.

\section{SWS運用の違いがダム貯水池の水環境に与える 影響の検討}

\section{（1）検討ケースの設定}

SWS運用の違いがダム貯水池の水環境に与える影響を 調べるため, まず, SWS運用の検討ケースの設定を行う。

土師ダムでは通常水深数前のところから表層取水を 行っている. そこで, Case 1として, 水深 $3 \mathrm{~m}$ 表層取水 を行うケースを基本とし, Case 2 として水深 $13 \mathrm{~m}$ の中層 取水を行うケース, Case 3 として水深 $3 \mathrm{~m}$ と $8 \mathrm{~m}$ の異高同 時選択取水を, Case 4として水深 $3 \mathrm{~m}$ と $13 \mathrm{~m}$ の異高同時選 択取水を行うケースの計4パターンのSWSの運用につい て検討を行う. 但し, 参考として行った実際の運用ケー スによる結果は, Case 1 とほぼ同様のものとなっていた。 計算に使用する流入河川流量やSWSを含むすべての取 水・放流設備におうる流量は, 実際の観測データを用い た. 土師ダムの取水・放流設備は, SWSの他, 発電用取 水（取水レベル13.5m），オリフィスゲート（放流レベ ル12.64m）を保有している. オリフィスからの放流は洪 水時であるが, 平水時の選択取水量は $3 \mathrm{~m}^{3} / \mathrm{s}$ 程度, 発電 用取水量は $7 \mathrm{~m}^{3} / \mathrm{s}$ 程度である. また, 異高同時選択取水 時の計算においては, 観測で得られている選択取水流量 を等分して2箇所の取水レベルから取水を行なった.

\section{（2）SWS運用の違いが水温成層に与える影響}

計算対象 3 年 $\times$ 各4ケース $=$ 全 12 ケースの計算を行った 結果の中で, 水温とDOの季節変化を図-2に示す.

まず，図-2の水温分布に着目する．従来通りの1つの 高さから取水するCase 1 とCase 2を比較すると，各年と も取水高さがより深いCase 2の方が水温躍層も低くなる, あるいは成層が破壊されていることが分かる. 異高同時 選択取水を行ったCase 3 とCase 4についてみると, より 深いところで取水するCase 4の方が水温躍層も低い傾向 があることが分かる. この成層状況の特徽を詳しくみる ために, 鉛直方向の最大水温差と最下層のDO変化を図3に示す. 図-3(a), (c), (e)の最大水温差の図より, 各年と も6月頃までの受熱期においては, SWS運用の違いによ る大きな差は無く, 放熱期に入ってSWSの運用による差 を生じていることが分かる.

そこで放熱期以降に注目すると，図-3(a)に示す1994年
は, Case 1, 3, 4, 2 と平均的な取水水深が深くなるに従い, 8月中旬以降の最大水温差が小さくなり, 成層が弱く なっている. また，同図(c)の1997年は，放熱期に入り， Case 2の最大水温差はCase 1よりも大きくなっている. これは，この年6月下旬の中規模出水時前には, 両ケー スの水面と最下層における水温はそれほど変わらない值 を示しているが, Case 1の水温躍層がCase 2より浅く, 全体的に緩やかな水温勾配を示すのに対し, Case 2では $10^{\circ} \mathrm{C}$ 以上のはっきりとした水温躍層を持っているため, 中層付近に流入した中規模出水が, Case 1では中層以梁 の弱い水温成層を破壞しダム底部まで水温を上昇させる のに対し, Case 2では $10^{\circ} \mathrm{C}$ 上の水温差のある温度躍層 を破壊することができず最下層部に冷たい水温が残った ためである. また，異高同時選択取水を行ったCase 3,4 では, Case 1,2の中間的な挙動を示すのではなく, Case 1より最大水温差が小さく弱い水温成層構造となってい る. さらに, 同図(e)の1999年は, 6月末の大規模出水の とき, Case 1以外では, 水温成層が破壊されダム底まで ほぼ一様な水温となったため, それ以降のSWS運用の違 いによる最大水温差に大きな差がなく, Case 1 のみが成 層が破壊されなかったため, 大きな水温差が9月下旬ま で継続している.

このように，基本的には，より深い層から取水するこ とは躍層位置を下げる効果を持つため, 洪水流入時や強 風時に最下層まで混合しやすい傾向を持つ. しかしなが ら，時には，より深い層での取水は，下層において大き な水温躍層を形成し，水温躍層が破壊されにくくなるこ とがある. SWS運用においては，取水位置を下げ躍層位 置を下げるとともに, 水温勾配が緩やかな水温成層構造 を形成することも重要である. このためには, 異高同時 SWSのように, 複数の高さからの取水が有効である.

\section{（3）SWS運用の違いがダム貯水池の水質に与える影響}

貯水池における長期濁水化に代表されるSSについての 問題は, 水温成層の状況とともに洪水時のSWSの操作が 重要であり, 本研究で対象としている単純操作における 結果から考察を行うことはできない. したがって,ここ で扱う水質問題として, 富栄養化に関するChl.a と, 貧酸 素化に関するDOを対象として考察を行う。

ダム貯水池のChl.a濃度は表層で高くなる. そこで，今 回の検討ケースにおける表層での日平均のChl.a濃度が 25 $\mu \mathrm{g} / \mathrm{L}$ 以上となる日数を表-1に示す.これから分かるよ うに, SWSの運用の違いは, 植物プランクトンの発生に あまり影響を与えていない.これは，土師ダムのように 富栄養化した湖沼では, 表層における植物プランクトン の成長は表層の水温に左右されることが多く, この表層 の水温は, 主に, 日々の日射などの気象条件に作用され， SWSの運用がほとんど影響を与えないためである. 次に DOについて考察する. 


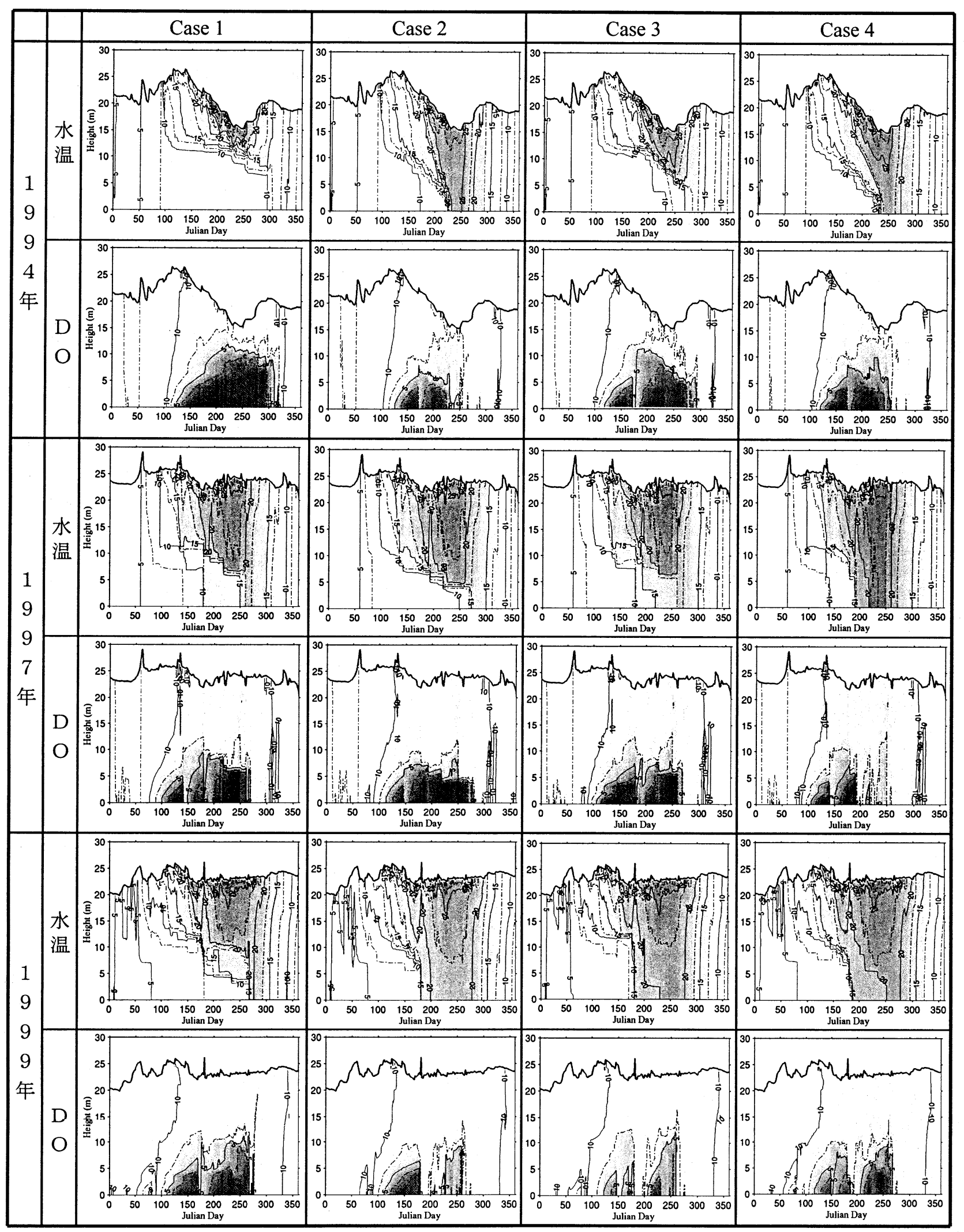

図-2 SWS運用の違いによる水温・DOの季節変化

まず，図-2に示すDOの季節変化をみる，DOの分布は， 水温構造に影響されていることが分かる. 寸なわち，水 温成層が形成される4月から10月は，深水層で貧酸素状 態となり，洪水の流入に伴って水温成層が破壊されDO は一旦回復しても, その後再び貧酸素状態となっている.
放熱期である11月から3月までは，水温の鉛直分布はほ ぼ一定であり，貧酸素状態となることはない．

ここで，最下層DOの変化を示した図-3(b), (d), (e)より, 各年とも, 最大水温差が大きくなるSWS運用が, 最下層 DOも低くなっていることが分かる，各年毎にみると， 


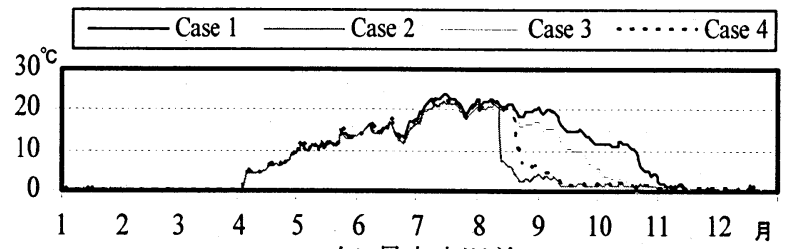

(a) 1994年 最大水温差

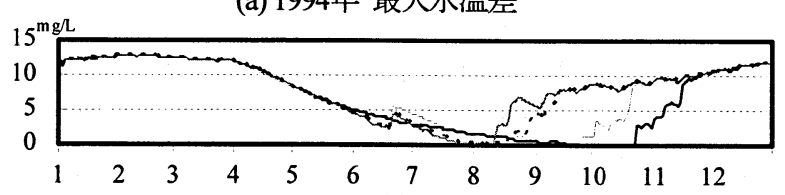

(b) 1994年 最下層DO

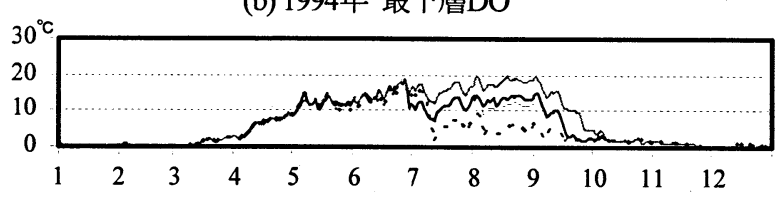

(c) 1997年 最大水温差

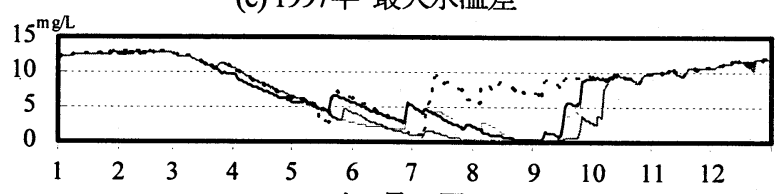

(d) 1997年 最下層DO

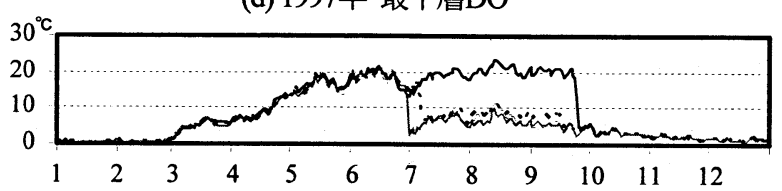

(e) 1999年 最大水温差

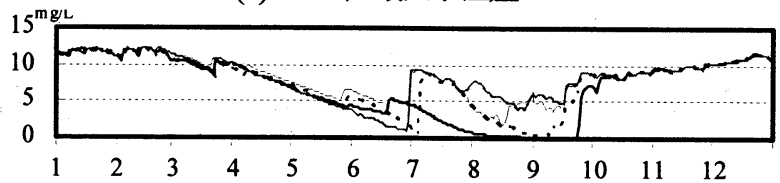

(f) 1999年 最下層DO

図-3 各ケースにおける最大水温差と最下層DOの変化

表-1 表層Chl.a $\geqq 25 \mu \mathrm{g} / \mathrm{L}$ となる日数

\begin{tabular}{|c|c|c|c|c|}
\hline & Case 1 & Case 2 & Case 3 & Case 4 \\
\hline 1994年 & 95 & 85 & 84 & 82 \\
\hline 1997年 & 70 & 65 & 61 & 69 \\
\hline 1999年 & 41 & 36 & 49 & 38 \\
\hline 計 & 206 & 186 & 194 & 189 \\
\hline
\end{tabular}

表-2 最下層DO $\leqq 2 \mathrm{mg} / \mathrm{L}$ となる日数

\begin{tabular}{|c|c|c|c|c|}
\hline & Case 1 & Case 2 & Case 3 & Case 4 \\
\hline 1994年 & 92 & 35 & 67 & 49 \\
\hline 1997年 & 45 & 99 & 52 & 10 \\
\hline 1999年 & 68 & 12 & 2 & 41 \\
\hline 計 & 205 & 146 & 121 & 100 \\
\hline
\end{tabular}

渴水年である1994年は, 水温成層についての考察と同様 に，取水高さが低くなるCase 1, 3, 4, 2の順に最下層DOの 状態は覀くなっている. また，1997年では，Case 4 が一 番DOの状態が良い.これは，最大水温差でみたように， Case4のみが7月中旬の中規模出水時に水温成層が破壊さ れるため，DOもこの時に回復していることによる. 1999年では，6月下旬の大出水によりCase 1以外は成層

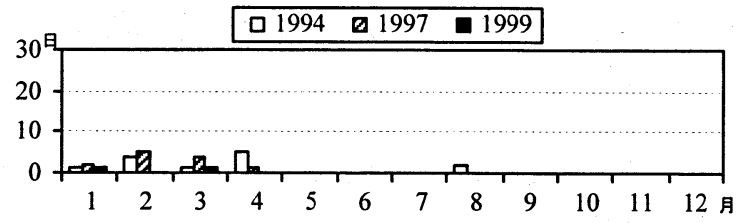

(a) Case1

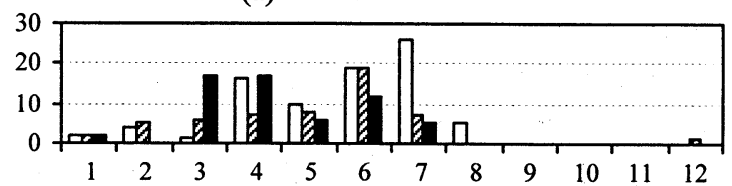

(b) Case 2

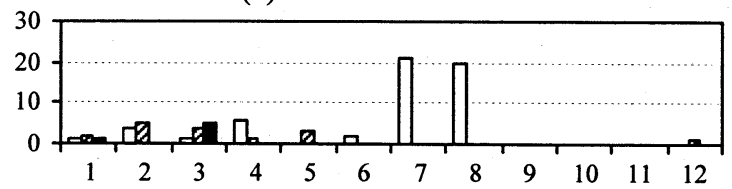

(c) Case 3

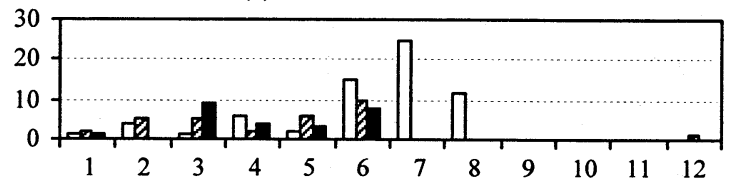

(d) Case 4

図-4 SWSが泠水放流する月別日数

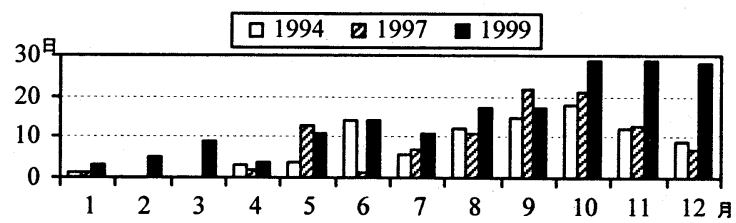

(a) Casel

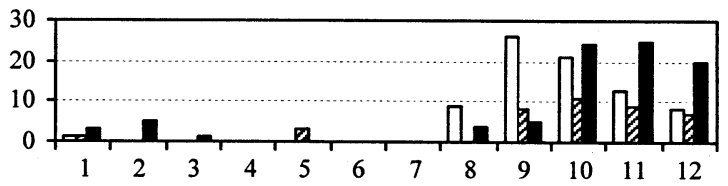

(b) Case 2

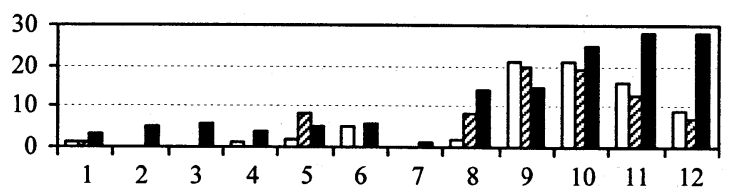

(c) Case 3

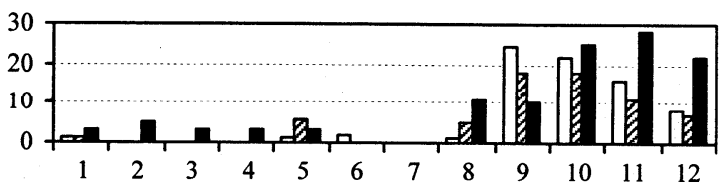

(d) Case 4

図-5 SWSが温水放流する月別日数

が破壊し，DOも一度回復しているが，その後，Case 2以 外は再び貧酸素化している.

ここで，DOの基準として湖沼の水質環境基準C類型を 参考に, 日平均の最下層のDOが $2 \mathrm{mg} / \mathrm{L}$ を回る日数を調 べた結果を表-2に示す。これによると，Case 3あるいは Case 4のような同時選択取水は，Case 1の表層取水より， 深水層の貧酸素化を発生させる可能性は少ない. 


\section{SWS運用の違いがダムからの放流水に与える影 響の検討}

SWSが放流水に与える影響を考える場合, 通常DOが 放流水で問題となることは少なく, Chl.aも表層取水を 行ったときにのみ問題となる. そこで，ここでは水温を 対象に検討を行う。また，水温については，冷水放流が 問題となることが多いが，河川の生態系を考えると，本 来流れている河川水の水温より高くなる温水放流も好ま しくない. そこで, 水温については, 日平均した值をも とに，ダム貯水池流入地点での河川水温を基淮にして, 選択取水からの放流水が $2^{\circ} \mathrm{C}$ 以上低くあるいは高くなる 日数を月別にカウントしたものを図-4, 図-5に示す.

図-4の冷水放流という観点からは, 表層取水のCase 1 では，冷水問題が発生することは少なく，Case 2のよう に中層取水を行う運用が一番問題となることが分かる.

異高同時選択取水を行うケースについては，1994年のよ うな渴水年では，水位の低下した6〜8月の夏季に強い水 温成層が形成され，水深 $13 \mathrm{~m}$ の取水が底層からの取水と なっており，その影響で泠水が放流されることもある.

しかし，このような特異な状況でなければ，異高同時選 択取水からの冷水放流はそれほど問題とならない，一方， 図-5の温水放流という観点からは，どのケースをみても， 9月〜12月の放熱期に多く発生している. また，表層取 水のCase 1は年間 100 日以上の温水放流を行っており, 河川の生態系に与える影響が大きい可能性がある.

\section{5. おわりに}

ダム貯水池における水質管理対策として，SWSの異高 同時選択取水という現在日本で積極的になされていない 運用ケースを含めた選択取水方式の検討を行った. ここ で, 本研究で得られた主要な結論をまとめる.

1） CWRで開発された1次元の貯水池流動水質予測モデ ルDYRESM-CAEDYMに，鉛直混合過程を組み込むこと により，日本のダム貯水池における長期の水質予測を十 分な精度で行うことができることを明らかにした.

2) SWSの運用による貯水池内の水環境を考えた場合, 哚水層の貧酸素化を防ぐためには，できるだけ強固な成 層を形成しないようにすることが重要である.このため, 普段から低い層からの取水を含む選択取水を行い水温躍 層を下げておくとともに，洪水流入や強風時に成層が破 壊されやすくするため, 異高同時取水のように複数の高 さから取水を行い，貯水池内の水温勾配を緩やかにして おくことが必要である．また，SWSの運用は，貯水池表 層でのプランクトンの増殖にあまり影響を与えない.

3) SWSからの放流水の水温を調べた結果, 表層選択取 水の場合，冷水放流はほとんど問題とならないが，長期 にわたり温水放流している危険性があり，河川の生態系 にとっては問題である. 一方, 異高同時選択取水を行っ
た場合は，9月以降の放熱期における温水放流は避けに くいが，夏期のかんがい期においては，渇水年のように 浅い水深で強固な水温成層が形成され，貯水位も低い場 合はさらに検討を要するが，一般的な流況の年では，冷 水・温水放流のどちらも避けられる可能性がある.

以上の成果を踏まえ, 今後は, 高度な水質予測計算モ デルを用い，季節や貯水池の成層状況などを考慮した多 様なSWS運用ルールの検討を行う必要がある．また，同 時に，既存の運用ルールについても，その情報収集と分 析を行うべきである.

謝辞 : ここで使用した土師ダムに関するデータは，国土 交通省中国地方整備局土師ダム管理所から提供して頂い た.また，本研究で使用したモデルは，国土交通省中国 地方整備局殿ダム工事事務所から委託を受けた，鳥取大 学における受託研究「殿ダム貯水地内及び下流河川の水 質予測評価」の研究成果を使用している。ここに記して 謝意を表する.

\section{参考文献}

1) Jorg Imberger : Selective withdrawal (a review), the $2^{\text {nd }}$ International Symposium on Stratified Flows, Vol.1, pp.381-340, 1980.

2) Jacques Gaillard : Multilevel withdrawal and water quality, J. Environmental Eng., Vol.110, No.1, pp.123-130, 1984.

3) 高棹环馬・池淵周一・小尻利治 : 濁質水を考慮したダム制御 に関する一考察, 京都大学防災研究所年報, 第22 号B-2, pp.167-178, 1979.

4) Darrell G. Fontane, Hohn W. Labradie and Bruce Loftis : Optimal control of reservoir discharge quality through selective withdrawal, Water Resour. Res., Vol.17, No.6, pp.1594-1604, 1981.

5) 堀田哲夫・陳飛勇・山下芳浩・東海林光 : 成層型ダム湖にお ける濁水特性と選択取水効果に関する事例的研究, 水工学論 文集, 第46巻, pp.1079-1084, 2002.

6) 高野浩一・左近重信・及川拓治 : 高濁度放流期間の短縮を目 的とした早明浦ダムの取水設備の改造と運用, 大ダム, NO.187, pp. 3-15, 2004 .

7) 川崎秀明 : ダム技術の動向と課題, ダム日本, No.700, pp.2133, 2003.

8) 吉田延雄・中村徹 : 選択取水設備の運用効果について, 平成 11年度ダム水源地環境技術研究所所報, pp.30-37, 2000 .

9) The Task Committee on Outlet Works, Committee on Hydraulic Structures : Register of selective withdrawal works in unites states, J.Hydraulics division, Proceedings of the American Society of Civil Engineers, Vol.96, No.HY9, pp.1841-11872, 1970.

10) Tracy B.Vermeyen, Connie DeMoyer, Wayne Delzer and Dennis Kubly (Bureau of Reclamation, Co) : A survey of selective withdrawal systems (Final rept.), 2003.

11) Jason Antenucci : User Guide for the coupled CWR dynamic reservoir simulation model and computational aquatic ecosystems dynamic model DYRESM-CAEDYM, 2003.

12) 道奥康治・松尾昌和・香川健一・斉藤敦 : 貯水池の富栄養 化にともなう熱塩成層のモデル化，水工学論文集，第 47 巻, pp.1237-1242, 2003.

(2004.9. 30 受付) 